\title{
PENGELOLAAN KURIKULUM PROGRAM STUDI PENDIDIKAN GURU SEKOLAH DASAR PADA PERGURUAN TINGGI
}

\author{
Sri Setyaningsih \\ IKIP Veteran Semarang \\ ningsih16@yahoo.com
}

\begin{abstract}
Generally, this study aimed to describe the curriculum management study program Elementary School Teacher in Higher Education. The specific objective of this study to describe the planning, implementation and evaluation of curriculum type of qualitative research based approach. The location or background of this research are two colleges in Hyderabad and one college in Surakarta. The data source is a research university leaders, faculty, and students of Elementary School Teacher research site. Data collection techniques, participant observation, indepth interviews and document study. The results of the research, curriculum management organization of Primary School Teacher Education, related to the planning, implementation, and evaluation. Curriculum planning Elementary School Teacher each college has a trademark in accordance with the vision and mission. Implementation of the curriculum with regard Kridit Semester System load varies at each college. Evaluation of the curriculum is based on the potential and dynamics of each perguruang high.
\end{abstract}

Keywords: curriculum, teacher education, colleges, primary schools

\begin{abstract}
Abstrak. Secara umum penelitian ini ditujukan untuk mendeskripsikan pengelolaan kurikulum Program Studi Pendidikan Guru Sekolah Dasar di Perguruan Tinggi. Tujuan khusus penelitian ini untuk mendeskripsikan perencanaan, pelaksanaan dan evaluasi kurikulum Jenis penelitian berdasarkan pendekatannya kualitatif. Lokasi atau latar penelitian ini adalah dua perguruan tinggi di Semarang dan satu perguruan tinggi di Surakarta. Sumber data penelitian adalah pimpinan perguruan tinggi, dosen, dan mahasiswa Pendidikan Guru Sekolah Dasar tempat penelitian. Teknik pengumpulan data, observasi partisipan, wawancara mendalam, dan studi dokumen. Hasil penelitian, Pengelolaan kurikulum penyelenggaraan Pendidikan Guru Sekolah Dasar, terkait dengan perencanaan, pelaksanaan, dan evaluasi. Perencanaan kurikulum Pendidikan Guru Sekolah Dasar masing-masing perguruan tinggi memiliki ciri khasnya sesuai dengan visi dan misinya. Pelaksanaan kurikulum dengan memperhatikan beban Sistem Kridit Semester yang bervariasi pada masingmasing perguruan tinggi. Evaluasi kurikulum didasarkan pada potensi dan dinamika masing-masing perguruang tinggi.
\end{abstract}

Kata kunci: kurikulum, pendidikan guru, perguruan tinggi, sekolah dasar

\section{Pendahuluan}

Pentingnya kurikulum dalam pengelolaan Pendidikan Guru Sekolah Dasar (PGSD) di Perguruan Tinggi untuk keseimbangan antara kepentingan nasional dan kepentingan daerah. Kompetensi dan materi kurikulum dikembangkan berdasarkan keharmonisan antara kepentingan nasional untuk 
membangun kehidupan berbangsa yang kuat dan bermartabat dengan kepentingan daerah baik kepentingan sosial-budaya-ekonomi setempat maupun dalam kontribusinya terhadap pengembangan kehidupan daerah dan sebaliknya kepentinagn daerah tidak boleh diabaikan demi kepentingan nasional. Beauchamp (dalam Zaini, 2006:4), mengemukakan bahwa kurikulum memuat kepentingan nasional dan daerah sebagai bagian dari rencana pendidikan atau pengajaran.

Undang-undang Republik Indonesia Nomor 20 Tahun 2003 tentang Sistem Pendidikan Nasional mengatur kurikulum pendidikan sebagaimana tercantum pada Bab X pasal 36, pasal 37, dan pasal 38 . Pengembangan kurikulum dilakukan dengan mengacu pada standar nasional pendidikan untuk mewujudkan tujuan pendidikan nasional (pasal 36 ayat 1), kurikulum pada semua jenjang dan jenis pendidikan dikembangkan dengan prinsip diversifikasi sesuai dengan satuan pendidikan, potensi daerah, dan peserta didik (pasal 36 ayat 2). Yang dimaksud dengan pengembangan kurikulum dengan prinsip diversifikasi adalah suatu pengembangan yang memungkinkan penyesuaian program pendidikan pada satuan pendidikan dengan kondisi dan kekhasan potensi yang ada di daerah.

Hasil penelitian Wiley (2012: 3) tentang Kurrikulum menegaskan bahwa kurikulum berarti dua hal: 1) berbagai program studi dari mana mahasiswa memilih apa materi untuk belajar; dan 2) program pembelajaran tertentu. Dalam kasus terakhir, kurikulum kolektif menggambarkan pengajaran, pembelajaran, dan bahan penilaian yang tersedia untuk kursus tertentu studi. Saat ini, kurikulum dipromosikan sebagai dasar yang memungkinkan siswa untuk meninjau kembali isi suatu materi pelajaran di tingkat perkembangan yang berbeda dari materi pelajaran yang sedang dipelajari.Pendekatan konstruktivis, dari kurikulum, mengusulkan bahwa mahasiswa belajar lebih baik melalui keterlibatan aktif dengan lingkungan pendidikan, yaitu penemuan pembelajaran.

Hasil penelitian Crown (2012:1) tentang The School Curriculum menyatakan bahwa persyaratan kurikulum untuk akademi ditetapkan dalam perjanjian pendanaan mereka. Umumnya, akademi dan sekolah gratis harus menyediakan kurikulum yang luas dan seimbang antara bahasa Inggris, Matematika, dan ilmu pengetahuan serta membuat ketentuan pengajaran pendidikan agama. Selain ini mereka memiliki kebebasan untuk merancang kurikulum yang memenuhi kebutuhan murid mereka, aspirasi dan kepentingan. Pemerintah telah meluncurkan penelaahan terhadap Kurikulum Nasional di Inggris dengan tujuan untuk mengembangkan kurikulum yang koheren yang memungkinkan mahasiswa membangun pengetahuan mereka secara sistematis dan konsisten, dan mendukung transisi pemanfaatan saraana prasarana.

Kurikulum PGSD sangat penting, karena PGSD diharapkan menghasilkan tenaga pendidikan yang mampu bekerja maksimal untuk mencerdaskan kehidupan bangsa. Raiser (2012: 1) mengemukakan bahwa: sekolah dasar dalam satuan waktu usia anak-anak memulai memperoleh pengetahuan yang bertindak sebagai dasar untuk menerima pendidikan mereka. Sebagai guru sekolah dasar, bekerja dengan suatu kelas dari para siswa, di mana usianya mulai dari enam sampai dua belas tahun. Biasanya, para guru sekolah dasar bertanggung jawab atas mengajar berbagai mata pelajaran pada kelompok kelas yang sama, maka kecakapan yang dimliki guru sekolah dasar minimal matematika, ilmu pengetahuan, bahasa, dan ilmu kemasyarakatan. Para guru sekolah dasar pada umumnya bekerja penuh waktu, berbeda dengan guru mata pelajaran. Karena sejumlah tugas-tugas yang diperlukan untuk mencapai keberhasilan dalam menjalankan tugas di kelas, banyak guru bekerja lebih dari 40 jam per minggu. Para guru sekolah dasar diperkenankan melakukan tugas-tugas yang khas seperti membimbing siswa. 
Lebih lanjut Raiser menekankan bahwa sekolah dasar adalah pondasi untuk pendidikan anak-anak. Sebagai guru sekolah dasar, bekerja dalam suatu kelas bersama siswa, yang berusia enam sampai dua belas tahun. Biasanya, para guru sekolah dasar bertanggung jawab atas pembelajaran berbagai materi pelajaran, maka kecakapan ilmu pengetahuan, bahasa, dan ilmu kemasyarakatan diperlukan. Para guru sekolah dasar pada umumnya bekerja fulltime untuk suatu tahun pelajaran tradisional yang 10 bulan dengan musim panas batal. Karena sejumlah tugas-tugas yang diperlukan untuk dengan sukses menjalankan kelas tidak bisa diselesaikan selama sekolah hari yang reguler, banyak guru bekerja lebih dari 40 jam per minggu. Para guru sekolah dasar boleh melakukan tugas-tugas yang berikut selama suatu hari yang khas yang manapun.

Siddiqui (2009:4) menyatakan kerangka Kurikulum Nasional untuk Pendidikan Guru menegaskan bahwa mutu guru adalah suatu ditentukan oleh beberapa faktor-faktor, misalnya status guru, penggajian, kondisikondisi pekerjaan, pendidikan guru yang professional, dan kualifikasi akademis. Sistim pendidikan guru berawal dari melalui program profesional yang diharapkan mampu memenuhi kebutuhan para guru secara professional, berkompeten untuk menjalankan tugas-tugas sekolah. Pendidikan guru terutama, mempunyai suatu bagian terbesar di dalam menghasilkan calon-calon guru yang profesional. Itu menandai inisiatif pemanggilan bagi calon guru baru dan seperti halnya mempunyai potensi luar biasa untuk mengilhami calon guru dengan motivasi yang tepat, pengetahuan, ketrampilan-ketrampilan, dan sikap-sikap. Secara mendasar dari pendidikan guru adalah mutu kinerja guru dalam kaitan dengan dengan menggunakan istilah dampaknya bagi siswa dan secara tidak langsung melaksanakan perubahan bentuk sosial yang lebih besar.

Salah satu tugas utama guru adalah melaksanakan kegiatan pembelajaran berdasarkan kurikulum yang berlaku.
Dengan demikian pemahanam terhadap kurikulum sampai dengan strategi pelaksanaan sangat penting. Kurikulum merupakan rancangan pendidikan yang merangkum semua pengalaman belajar yang disediakan bagi siswa di sekolah. Dalam kurikulum terintegrasi filsafat, nilai-nilai, pengetahuan, dan perbuatan pendidikan kurikulum disusun oleh para ahli pendidikan/ ahli kurikulum, ahli bidang ilmu, pendidik, pejabat pendidikan, pengusaha serta unsurunsur masyarakat lainnya. Rancangan ini disusun dengan maksud memberi pedoman kepada para pelaksana pendidikan, dalam proses pembimbingan perkembangan siswa, mencapai tujuan yang dicita-citakan oleh siswa sendiri, keluarga maupun masyarakat.

Menurut Webster dalam Yamin(2012:21), kurikulum adalah jarak yang ditempuh oleh pelari atau kereta dalam perlombaan. Kurikulum juga bermakna seperti kereta pacu di zaman lampau yitu suatu alat yang membawa seseorang dari garis start sampai finish. Dalam sektor pendidikan kurikulum berarti sejumlah mata pelajaran di perguruan tinggi.

Kurikulum sebagai rencana pengajaran, rencana belajar murid, dan pengalaman belajar yang diperoleh murid dari sekolah/ madrasah. Kurikulum memuat sejumlah mata pelajaran yang membentuk intelektual manusia menguasai mata pelajaran, mencapai tujuan belajar (Hidayat, 2013:19).

Kurikulum dalam arti sempit adalah semua pelajaran baik teori maupun praktik yang diberikan kepada siswa selama mengikuti proses pendidikan tertentu, yang terbatas pada pemberian bekal pengetahuan dan keterampilan untuk kepentingan siswa dalam melanjutkan maupun memasuki dunia kerja. Sedangkan dalam pengertian luas, kurikulum adalah semua pengalaman yang diberikan oleh lembaga pendidikan kepada anak didik selama mngikuti pendidikan (Arikunto dan Lia, 2012: 95).

Berdasarkan uaraian tersebut, kurikulum dimaksudkan sebagai kumpulan mata pelajaran dan sejumlah pengalaman belajar 
yang diberikan lembaga pendidikan kepada siswa/mahasiswa untuk melanjutkan sekolah/ pendidikan ke jenjang yang lebih tinggi dan atau memenuhi kebutuhan dunia pekerjaan. Kurikulum dapat dikembangkan sesuai prinsip relevansi, fleksibilitas, kontinuitas, praktis, dan efektivitas (Sukmadinata, 2006: 150-151).

Prinsip pertama, ada dua macam relevansi yang harus dimiliki kurikulum yaitu relevan ke luar maksudnya tujuan, isi, dan proses belajar yang tercakup dalam kurikulum hendaknya relevan dengan tuntutan, kebutuhan, dan perkembangan masyarakat. Kurikulum menyiapkan siswa untuk bisa hidup dan bekarja dalam masyarakat. Apa yang tertuang dalam kurikulumhendaknya mempersiapkan siswa untuk tugas tersebut. Kurikulum bukan hanya menyiapkan anak untuk kehidupannya sekarang tetapi juga yang akan datang, juga harus memiliki relevansi didalamnya, yaitu ada kesesuaian atau konsistensi antara komponen-komponen kurikulum, yaitu antara tujuan, isi, proses penyampaian, dan penilaian. Relevansi interval ini menunjukkan suatu keterpaduan kurikulum.

Prinsip kedua adalah fleksibilitas, kurikulum hendaknya memilih sifat lentur atau fleksibel. Kurikulum mempersiapkan anak untuk kehidupan sekarang dan yang akan datang, disini dan tempat lain bagi anak yang memiliki latar belakang dan kemampuan yang berbeda.Suatu kurikulum yang baik adalah kurikulum yang berisi halhal yang solid, tetapi dalam pelaksanaanya memungkinkan terjadinya penyesuaianpenyesuaian berdasarkan kondisi daerah, waktu maupun kemampuan dan latar belakang anak.

Pinsip ketiga adalah kontinuitas yaiu kesinambungan. Perkembangan dan proses belajar anak berlangsung secara berkesinambungan, tidak terputus-putus atau berhenti-henti. Oleh karena itu, pengalamanpengalaman belajar yang disediakan kurikulumjugahendaknya berkesinambungan antara satu tingkat kelas, dengan kelas lainnya, antara satu jenjang pendidikan dengan pekerjaan. Pengembangan kurikulum perlu dilakukan serempak bersama-sama, perlu selalu ada komunikasi dan kerja samaantara para pengembang kurikulum sekolah dasar dengan SLTP, SLTA dan Perguruan Tinggi.

Prinsip keempat adalah praktis, mudah dilaksanakan, menggunakan alat-alat sederhana dan biayanya juga murah. Prinsip ini juga disebut prinsip efisiensi. Betapapun bagus dan idealnya suatu kurikulum kalau menuntut keahlian-keahlian dan peralatan yang sangat khusus dan mahal pula biasanya, maka kurikulum tersebut tidak praktis dan sukar dilaksanakan.kurikulum dan pendidikan selalu dilaksanakan dalam keterbatasanketerbatasan, baik keterbatasan waktu, biaya, alat,maupun personalia. Kurikulum bukan hanya harus ideal tetapi juga praktis.

Prinsip kelima. adalah efektivitas. Walaupun kurikulum tersebut harus murah, sederhana, dan murah tetapi keberhasilannya tetap harus diperhaikan. Keberhasilannya tetap harus diperhatikan. Keberhasilan pelaksanaan kurikulum ini baik secara kuantitas maupun kualitas. Pengembangan suatu kurikulum tidak dapat dilepaskan dan merupakan penjabaran dari perencanaan pendidikan. Perencanaan dibidang pendidikan juga merupakan bagian yang dijabarkan dari kebijakan-kebijakan pemerintah di bidang pendidikan. Keberhasilan kurikulum dapat mempengaruhi keberhasilan pendidikan. Kurikulum pada dasarnya berintikan empat aspek utama yaitu: tujuan-tujuan pendidikan, isi pendidikan, pengalaman belajar dan penilaian.

Pengelolaan kurikulum merupakan suatu rangkaian kegiatan rancangan atau membuat suatu perencanaan, pelaksanaan, dan evaluasikurikulum yang merangkum semua pengalaman belajar yang disediakan bagi mahasiswa di perguruan tinggi. Dalam kurikulum terintegrasi filsafat, nilai-nilai, pengetahuan, dan perbuatan pendidikan kurikulum disusun oleh para ahli pendidikan/ ahli kurikulum, ahli bidang ilmu, pendidik/ dosen, pejabat pendidikan, pengusaha serta 
unsur-unsur masyarakat lainnya. Rancangan ini disusun dengan maksud memberi pedoman kepada para pelaksana pendidikan, dalam proses pembimbingan perkembangan mahasiswa, mencapai tujuan yang dicitacitakan oleh siswa sendiri, keluarga maupun masyarakat.

Secara umum penelitian ini ditujukan untuk mendeskripsikan pengelolaan kurikulum Program Studi PGSD di Perguruan Tinggi. Tujuan khusus penelitian ini untuk mendeskripsikan perencanaan, pelaksanaan dan evaluasi kurikulum Program Studi PGSD di Perguruan Tinggi.

\section{Metode}

Jenis penelitian ini berdasarkan pendekatannya kualitatif. Disebut kualitatif, karena sifat data yang dikumpulkannya bercorak kualitatif, bukan kuantitatif yang menggunakan alat-alat pengukur. Pengunaan pendekatan ini dianggap lebih tepat karena fokus penelitian ini lebih banyak menyangkut proses dan memerlukan pengamatan yang mendalam dengan setting alami. Hal ini sesuai dengan pendapat Marshall dan Rossman (1989) yang menyatakan bahwa untuk meneliti suatu proses diperlukan pendekatan kualitatif. Selain itu penggunaan pendekatan ini dimaksudkan untuk memahami perilaku manusia dari kerangka acuan si pelaku sendiri, yakni bagaimana si pelaku memandang dan menafsirkan kegiatan dari segi penderiannya yang biasa disebut "persepsi emic"'(Nasution, 1996:32, Hakim, 1997:26).

Lokasi atau latar penelitian ini adalah dua perguruan tinggi di Kabupaten Semarang, yaitu Universitas Negeri Semarang, IKIP PGRI Semarang, dan satu perguruan tinggi di Surakarta yaitu Universitas Muhammadiah Surakarta (UMS).

Sumber data penelitian adalah pimpinan perguruan tinggi, dosen, dan mahasiswa PGSD tempat penelitian. Dalam penelitian ini digunakan tiga teknik pengumpulan data yaitu: teknik observasi partisipan (participant observation), wawancara mendalam (indepth interview), dan studi dokumen (Bogdan \&
Biklen, 1998; Nasution, 1996).

Analisis data dalam penelitian ini dilakukan selama dan setelah pengumpulan dayta sampai terselesaikannya laporan penelitian. Analisis data terdiri dari tiga kegiatan yang terjadi secara bersamaan, yaitu reduksi data, penyajian data, penarikan kesimpulan (Milles \& Hubberman, 1984). Teknik analisis data dalam penelitian adalah teknik induktif konseptualistik dalam arti informasi-informasi empiris yang diperoleh dan dibangun konsep-konsep atau proposisi-proposisi ke arah pengembangan suatu teori substantif. Tipe dasar proporsi pada dasarnya ada dua yaitu generalisasi empiris dan hipotesis. Generalisasi empiris bertolak dari data sedangkan hipotesis dikembangkan dari perbandingan data empiris dan hasil penelitian sedangkan hipotesis dikembangkan dari perbandingan data empiris dan hasil-hasil penelitian lain yang terkait. Dalam penelitian ini, kedua tipe proposisi tersebut sama-sama digunakan karena kesesuaiannya dengan karakteristik data yang dikehendaki.

\section{Hasil dan Pembahasan}

\section{Perencanaan kurikulum yang memenuhi kebutuhan mahasiswa}

Di Kasus I, perencanaan kurikulum penyelenggaraan pendidikan guru sekolah dasar (PGSD) Kasus I mengacu beban atau jumlah sks Program Studi (minimum untuk kelulusan) 144 sks yang terinci, yaitu : Mata kuliah wajib sebanyak 140 SKS, semua mahasiswa diwajibkan mengambil mata kuliah 140 sks. Mata kuliah pilihan sebanyak 4-9 SKS, semua mahasiswa wajib mengambil minimal 4 SKS mata kuliah pilihan dari 9 SKS mata kuliah pilihan yang disediakan. Jumlah total sebanyak 144-149 SKS, mahasiswa yang telah lulus 140 SKS mata kuliah wajib ditambah 4 SKS mata kuliah pilihan dinyatakan lulus S-1 PGSD. Mahasiswa diberi kesempatan mengambil mata kuliah pilihan lain tanpa paksaan bila ia menginginkan tambahan mata kuliah pilihan Tindakan perencanaan Program, Studi 
S-1 PGSD Kasus I dalam merancang dan mengimplementasikan program yang dilandasi oleh Visi, Misi, dan Tujuan, serta nilai-nilai akademik merupakan kekuatan internal yang mampu mendorong Prodi S-1 PGSD berprestasi dan mencapai keunggulan kompetitif. Nilai-nilai tersebut juga mengikat dan telah terinternalisasi pada sebagian kecil dosen dalam melaksanakan tugastugas profesionalnya, sehingga civitas academicamemiliki komitmen untuk secara kolaboratif dan partisipatif melaksanakan visi, misi, dan tujuan prodi. Akreditasi PGSD Kasus I dengan nilai akreditasi B (Baik) berdasarkan SK.BAN-PT No. 002/ BAN-PT/ $\mathrm{S} 1 / \mathrm{VI} / 2011$ dengan izin penyelenggaraan No. 3333/D/T/2006 tanggal 1 September 2006.

Pelaksanaan kurikulum sesuai dengan ketentuan yang berlaku dan ditetapkan Direktorat Jenderal Pendidikan Tinggi, muatan kurikulum yang di dalamnya terdapat sejumlah mata kulian yang ditawarkan di prodi ini antara lain Strategi Pembelajaran, Komputer dan Media Pembelajaran di SD, Pendidikan Bahasa Jawa, Bahasa Inggris, Konsep Dasar Pendidikan Kewarganegaraan, Matematika, Konsep Dasar IPA, Kajian Bahasa Indonesia SD, Kajian IPS SD, Psikologi Perkembangan, Pembelajaran Matematika SD, Konsep Dasar IPA, Keterampilan Berbahasa dan Bersastra Indonesia, Pendidikan Jasmani dan Kesehatan, Pendidikan IPS SD, Pendidikan Keterampilan dan Kerajinan Tangan, Pendidikan Lingkungan Hidup, Pendidikan Kewarganegaraan, Perspektif Global, Pendidikan IPA SD, Pembelajaran Bahasa dan Sastra Indonesia. SD Kelas Rendah, Pendidikan Kewarganegaraan SD, Bimbingan Konseling, Pembelajaran Matematika SD, Pendidikan Seni Drama Tari, Psikologi Pendidikan, Pendidikan Seni Rupa, Statistika Pendidikan, Pengembangan Konsep Dasar IPA, Manajemen Kelas, Pengembangan Kurikulum Muatan Lokal, dan Pendidikan Anak Berkebutuhan Khusus. Selain itu, Pendidikan Seni Musik, Pemecahan
Masalah Matematika, Pengembangan Kurikulum SD, Penelitian Pendidikan SD, Asesmen Pembelajaran SD, Pengembangan Pembelajaran IPA SD, Pembelajaran Bahasa dan Sastra Indonesia SD Kelas Tinggi, Pengembangan pembelajaran ips sd, penulisan karya ilmiah dan buku ajar, pembelajaran kelas rangkap, pengembangan pembelajaran bahasa indonesia sd, pengembangan pendidikan kewarganegaraan sd, profesi keguruan, penelitian pendidikan $\mathrm{SD}$, pengembangan pembelajaran matematika sd, pembelajaran terpadu, praktikum ipa, kuliah kerja nyata, pendidikan multikultural, pengembangan bahan pelajaran sd, skripsi, praktik pengalaman lapangan, pengantar ilmu pendidikan, filsafat pendidikan, dan manajemen sekolah.

Kegiatan ekstrakurikuler yang bisa diikuti mahasiswa ini anatara lain Himpunan Mahasiswa Jurusan (Hima), UKM Pramuka, UKM KSR, Warkop PGSD (Karya Ilmiah Mahasiswa), dan Teater. Lewat pembinaan kemahasiswaan, prestasi mahasiswa prodi ini antara lain juara II mahasiswa berprestasi PGSD se-Jawa, juara II Lomba Karya Ilmiah Se-Jawa, dan juara I Lomba Gagas Tulis Ilmiah Se-Jawa. Berdasar uraian di atas dipandang perlu adanya penguatan kelembagaan meliputi peningkatan kualitas staf pengajar dan administrasi menggunakan ICT, peningkatan kualitas kekerabatan dalam penelitian dan pengabdian kepada masyarakat, dan penciptaan lingkungan kerja yang lebih kondusif.

Selanjutnya, di Kasus II, perencanaan kurikulum untuk memberikan pelayanan akademik kepada mahasiswa guna menunjang proses pembelajarannya, Program Studi PGSD memberi tugas kepada para dosen untuk menjadi Pembimbing Akademik (PA). Karena jumlah mahasiswa setiap angkatan tidak terlalubanyak, maka dalam satu angkatan lebih dari satu dosen yang menjadi PA. Hal ini juga untuk meratakan tanggungjawan setiap dosen dalam membimbing mahasiswa setiap angkatannya. PA tidak hanya membimbing 
menjelang penyusunan KRS secara On-Line, tetapi juga membimbing mahasiswa yang bermasalah dalam bidang akademik.

Muatan kurikulum atau kuliah PGSD Kasus II, yaitu : Pendidikan Agama, Landasan Pendidikan, Psikologi Umum, IAD, Konsep Dasar PKn, Pengantar Dasar Matematika, Konsep Dasar IPA, Konsep Dasar IPS, Bahasa Inggris I (EAP), Pendidikan Kepramukaan, Studi Islam II, Pendidikan Kewarganegaraan, Psikologi Pendidikan, Strategi Belajar Mengajar, Komputer, Geometri dan Pengukuran, ISBD, Bimbingan dan Konseling, Perkembangan Peserta Didik, Bahasa Inggris II (TOEIC), Pendidikan IPS, Psikologi Perkembangan, Perencanaan Pembelajaran, Etika Profesi Pendidikan, Pengembangan Konsep Dasar IPA, Aritmatika, Manajemen Pendidikan, Penulisan Karya Ilmiah, Bahasa Indonesia, Media Pembelajaran dan ICT, Manajemen Kelas, Inovasi Pendidikan, Pendidikan IPA, Pembelajaran Geometri dan Pengukuran, Pembelajaran Bhs. Dan Sastra Indonesia, Studi Islam III, Pendidikan Seni Rupa dan Ketrampilan, Pendidikan Apresiasi Seni Krawitan, English Themes, Pendidikan Anak Berkebutuhan Khusus, Pembelajaran Terpadu, Evaluasi Pembelajaran, Penelitian Pendidikan, Pembelajaran Aritmatika, Pendidikan Kebudayaan Daerah, Pengembangan Pendidikan IPA, Pendidikan Apresiasi Seni Musik, Inovasi Pembelajaran, Kemampuan Berbahasa dan Bersastra, Teaching English for Children, Kajian Kurikulum PKn, Kepemimpinan Pendidikan, Statistika, Micro Teaching, Pengembagan Pembelajaran IPS, Pembelajaran Pemecahan Masalah Matematika, Penelitian Tindakan Kelas, Kajian Kurikulum Bahasa Indonesia, Pendidikan Jasmani dan Kesehatan Anak, Micro Teaching in English, PPL (Real Teaching), Kajian Lintas Budaya, Pendidikan Apresiasi Seni Wayang.

Mata kuliah di PGSD Kasus II terdiri atas mata Kuliah Wajib, 144 SKS, Mata Kuliah yang wajib diambil oleh seluruh mahasiswa terdiri dari MKU,MKKF, MKK Prodi. Mata Kuliah Pilihan SKS 4. Bagi mahasiswa yang memilih konsentrasi tertentu (Keminatan Pendidikan Bahasa Indonesia, Keminatan Matematika, Keminatan IPS, Keminatan IPA, Keminatan Bahasa Inggris,Keminatan Keskerta) setelah mengambil 18 sks tetapi tidak menulis skripsi, maka harus mengambil 2 MK yang ditentukan yang harus diambil sebanyak@2 sks.

Di Kasus III, perencanaan kurikulum untuk semua mahasiswa PGSD Universitas Muhammadiyah Surakarta diwajibkan mengambil mata kuliah wajib 144 SKS, dan wajib mengambil minimal 6 SKS mata kuliah pilihan dari 10 SKS mata kuliah pilihan yang disediakan. Mahasiswa yang telah lulus 144 SKS mata kuliah wajib ditambah 6 SKS mata kuliah pilihan dinyatakan lulus S-1 PGSD. Mahasiswa diberi kesempatan mengambil mata kuliah pilihan lain sebagai tambahan mata kuliah pilihan, kecuali untuk mata kuliah Pendidikan Islam dan Kemuhammadiyahan wajib diambil dan harus lulus minimal C.

PGSD Kasus III menyusun rancangan pengembangan, antara lain : 1. Mulai tahun akademik 2009/2010 meningkatkan efectivitas kerjasama dengan sekolah mitra dan sekolah laboratorium (Lab Shcool). Program Studi S1 PGSD FKIP UMS telah mengadakan perjanjian kerjasama dengan Sekolah Mitra (46 SDN se-Kecamatan Laweyan Surakarta, dan 22 Sekolah Muhammadiyah Surakarta). Sebagai sekolah lab adalah SD IT Muhammadiyah Al Kautsar, Gumpang - Karatasura); 2. Kurikulum PGSD mengarah pada hasil lulusan yang mampu menjadi guru Sekolah Dasar Bertaraf Internasional; 3. Mulai tahun akademik 2009/2010 akan menyelengarakan satu kelas SBI (25 mahasiswa) yang difasilitasi media pembelajaran ICT dan diampu dosen yang professional; 3. Empat tahun mendatang program Studi S1 PGSD bertambah 1 dosen tetap bergelar doctor (proses studi S3 di Western Australia), seorang dosen Magíster (proses studi; 4) 
S2 jurusan Primary Education di Australia, dan 6 orang dosen magíster program studi PGSD; 5) Melengkapi fasilitas laboratorium PGSD (kesenian, IPA, life skiil, Matematika, PKn); 6) Setiap tahun mahasiswa mengikuti lomba PKM dan LKTM dalam PIMNAS; 7) Penerbitan Jurnal Program Studi S1 PGSD.

Muatan kurikulum ata kuliah PGSD Kasus III, yaitu : Studi Islam I, Landasan Pendidikan, Psikologi Umum, IAD, Konsep Dasar PKn, Pengantar Dasar Matematika, Konsep Dasar IPA, Konsep Dasar IPS, Bahasa Inggris I (EAP), Pendidikan Kepramukaan, Studi Islam II, Pendidikan Kewarganegaraan, Psikologi Pendidikan, Strategi Belajar Mengajar, Komputer, Geometri dan Pengukuran, ISBD, Bimbingandan Konseling, Perkembangan Peserta Didik, Bahasa Inggris II (TOEIC), Kemuhammadiyahan, Pendidikan IPS, Psikologi Perkembangan, Perencanaan Pembelajaran, Etika Profesi Pendidikan, Pengembangan Konsep Dasar IPA, Aritmatika, Manajemen Pendidikan, Penulisan Karya Ilmiah, Bahasa Indonesia, Media Pembelajaran dan ICT, Manajemen Kelas, Inovasi Pendidikan, Pendidikan IPA, Pembelajaran Geometri dan Pengukuran, Pembelajaran Bhs. Dan Sastra Indonesia, Studi Islam III, Pendidikan Seni Rupa dan Ketrampilan, Pendidikan Apresiasi Seni Krawitan, English Themes, Pendidikan Anak Berkebutuhan Khusus, Pembelajaran Terpadu, Evaluasi Pembelajaran, Penelitian Pendidikan, Pembelajaran Aritmatika, Pendidikan Kebudayaan Daerah, Pengembangan Pendidikan IPA, Pendidikan Apresiasi Seni Musik, Inovasi Pembelajaran, Kemampuan Berbahasa dan Bersastra, Teaching English for Children, Kajian Kurikulum PKn, Kepemimpinan Pendidikan, Statistika, Micro Teaching, Pengembagan Pembelajaran IPS, Pembelajaran Pemecahan Masalah Matematika, Penelitian Tindakan Kelas, Kajian Kurikulum Bahasa Indonesia, Pendidikan Jasmani dan Kesehatan Anak, Micro Teaching in English, PPL (Real Teaching), Kajian Lintas Budaya, Pendidikan Apresiasi Seni Wayang \& Peran

\section{Pelaksanaan kurikulum sesuai perencanaan, menghasilkan lulusan sesuai visi dan misi almamater \\ Di Kasus I, pelaksanaan kurikulum} dan atau pembelajaran berpedoman pada Rancangan Mutu Perkuliahan (RMP) yang disusun berdasarkan kurikulum yang berlaku. Program Studi S1 PGSD menggunakan kurikulum yang berisi bidang-bidang kajian yang menjadi basis keilmuan S1 PGSD, yaitu bidang kajian hukum, politik, tatanegara, filsafat, dan sosial-budaya, serta ditunjang bidang Ilmu Pendidikan dan keterampilan pembelajaran. Hal itu dimaksudkan agar lulusan Program Studi S1 PGSD mampu berperan menjadi agen pembelajaran S1 PGSD yang profesional.

Di Kasus II, pelaksanaan kurikulum, mahasiswa Program Studi S1 PGSD selalu dilibatkan dalam proses belajar mengajar, di samping mengikuti perkuliahan, mahasiswa diberi pula peranan untuk mengontrol dosen dalam kegiatan proses belajar mengajar, seperti memonitor kehadiran dosen lewat jurnal perkuliahan dan mengevaluasi kinerja dosen setiap akhir semester.

Di Kasus III, Implementasi kurikulum dengan sistem kredit semester dijadikan dasar pengembangan diri mahasiswa. Hal ini berdasarkan realitas bahwa mahasiswa yang memiliki motivasi baik, dapat menyelesaikan studinya tepat waktu, memberi kesempatan mahasiswa untuk memilih beban mata kuliah yang ditempuh tiap semesternya, dan memberi peluang cuti jika menghadapi kendala dalam studinya. Mahasiswa mendapat pelayanan yang baik, seperti pelayanan akademik oleh Pembimbing Akademik (PA). Setiap ada kesulitan mahasiswa diberi kesempatan untuk berkonsultasi dengan PA-nya masingmasing. Di samping itu, pada setiap dialog kemahasiswaan selalu disertakan (diagendakan) penjelasan mengenai cara percepatan untuk menyelesaikan studinya. Selanjutnya, informasi yang berkaitan dengan kepentingan mahasiswa selalu diinformasikan lewat papan pengumuman yang mudah terbaca. 


\section{Evaluasi kurikulum melibatkan stakeholder akan menghasilkan pengembangan kurikulum yang baik}

Evaluasi kurikulum program studi S1 PGSD Kasus I, proses evaluasi dan penilaian secara komprehensif atas komitmen program studi terhadap mutu dan kapasitas penyelenggaraan program tridarma perguruan tinggi, untuk menentukan kelayakan program akademiknya. Evaluasi dan penilaian dalam rangka akreditasi program studi dilakukan oleh tim asesor yang terdiri atas pakar sejawat dan/atau pakar yang memahami penyelenggaraan program akademik program studi. Keputusan mengenai mutu didasarkan pada evaluasi dan penilaian terhadap berbagai bukti yang terkait dengan standar yang ditetapkan dan berdasarkan nalar dan pertimbangan para pakar sejawat. Buktibukti yang diperlukan termasuk laporan tertulis yang disiapkan oleh program studi yang diakreditasi, diverifikasi dan divalidasi melalui kunjungan atau asesmen lapangan tim asesor ke lokasi program studi.

Selanjutnya, di Kasus II, pentingnya evaluasi kurikulum dikembangkan berdasarkan keseimbangan antara kepentingan nasional dan kepentingan daerah. Kompetensi dan materi kurikulum dikembangkan berdasarkan keharmonisan antara kepentingan nasional untuk membangun kehidupan berbangsa yang kuat dan bermartabat dengan kepentingan daerah baik kepentingan sosialbudaya-ekonomi setempat maupun dalam kontribusinya terhadap pengembangan kehidupan daerah dan sebaliknya kepentingan daerah tidak boleh diabaikan demi kepentingan nasional. Tujuan akhir dari pengembangan kurikulum adalah pengembangun perencanaan pembelajaran dan penilaian pembelajaran (hasil belajar).

Di Kasus III, evaluasi kurikulum sebagai bagian dari pengembangan mutu pendidikan mempunyai kedudukan yang sangat strategis dalam seluruh aspek kegiatan pendidikan. Mengingat pentingnya peranan kurikulum di dalam pendidikan dan dalam perkembangan kehidupan manusia, maka dalam penyusunan kurikulum tidak bisa dilakukan tanpa menggunakan landasan yang kokoh dan kuat.

Plesiss (2005:18), mengemukakan bahwa Keberhasilan nyata implementasi kurikulum sangat ditentukan oleh perencanaan, desain, dan pelatihan yang dilakukan institusi sebelumnya dan dukungan dari pemerintah selama pelaksanaan kurikulum tersebut.

Kurikulum merupakan seperangkat rancangan pendidikan yang berisi pengalaman belajar yang diberikan kepada siswa di suatu sekolah, memberikan pedoman kepada para pelaksana pada lembaga pendidikan dalam proses belajar mengajar, mencapai tujuan yang dicita-citakan oleh siswa, keluarga maupun masyarakat sebagai stakeholders (Zaini, 2006: 81). Administrasi kurikulum mencakup penyusunan kurikulum, pembinaan kurikulum, pelaksanaan kurikulum, antara lain: pembagian tugas mengajar pada guruguru, penyusunan perencanaan pembelajaran atau rencana pengajaran tahunan, persiapan harian, mingguan, dan sebagainya (Purwanto, 2009:13). Kurikulum merupakan keseluruhan pengalaman yang akan dihayati oleh peserta didik di dalam lingkungan pendidikan. Di dalam pendidikan formal, kurikulum merupakan keseluruhan pengalaman, ilmu pengetahuan yang akan dihayati oleh peserta didik (Tilaar, 2005: 117). Kurikulum yang di dalamnya terdapat perencanaan pembelajaran bagi guru berfungsi sebagai dasar pengelolaan pembelajaran di kelas dimulai dari mulai perencanaan pelaksaan dan evaluasi pembelajaran, dan bagi sekolah berfungsi sebagai alat untuk mencapai tujuan pendidikan di sekolah dan sebagai pedoman yang dijadikan acuan dalam penyelenggaraan pendidikan di sekolah (Sudrajat, 2011: 3). Kurikulum tingkat satuan pendidikan adalah kurikulum operasional yang disusun, dilaksanakan, dan dievaluasi oleh masing-masing satuan pendidikan. Pemahamannya adalah bahwa pada tingkat satuan pendidikan, yaitu sekolah, harus dikembangkan kurikulum sesuai dengan kebutuhan dan kondisinya masing-masing.

Kurikulum harus mampu memberikan kontribusi dalam pengembangan perencanaan 
pembelajaran di satuan pendidikan sebenarnya bukan masalah yang asing dan baru bagi masing-masing sekolah. Sejak dahulu sekolah telah melaksanakan itu bersatu dengan perencanaan masing-masing sekolah dan perencanaan masing-masing guru. Hanya karena adanya Peraturan Pemerintah yang baru tentang standar pendidikan yang mengatur juga tentang pengembangan kurikulum satuan pendidikan maka perlu dilakukan penyesuaian-penyesuaian. Semoga aturan ini tidak menjadikan beban baru bagi guru maupun masing-masing satuan pendidikan.

Kurikulum harus mampu mengyelaraskan dan memenuhi tuntutan erkembangan dan perubahan yang terjadi dalam kehidupan bermasyarakat, berbangsa, dan bernegara di Indonesia tidak lepas dari pengaruh perubahan global, perkembangan ilmu pengetahuan dan teknologi, serta seni dan budaya. Perkembangan dan perubahan secara terus menerus ini menuntut perlunya perbaikan sistem pendidikan nasional termasuk penyempurnaan kurikulum untuk mewujudkan masyarakat yang mampu bersaing dan menyesuaikan diri dengan perubahan zaman tersebut.

Seharusnya sebuah kurikulum dipatenkan selama beberapa lama agar dapat dilihat hasil dari pembelajaran tersebut. Jika kita melihat kenegara lain yang lebih maju, mereka memiliki SDM yang bagus, itu karena siswa mereka tidak dibuat bingung oleh perubahan yang begitu cepat. Kurikulum yang lama belum terserap langsung sudah terganti. Hal lain adalah banyaknya pemborosan biaya pendidikan termasuk untuk mencetak bukubukuyangpadaakhirnya tidak terpakai,padahal seharusnya dapat digunakan untuk membiayai bidang-bidang lain dalam sektor pendidikan misalnya kesejahteraan guru, sehingga tidak akan terdengar lagi nada miris tentang nasib guru yang nyambi kerja jadi tukang ojek untuk mempertahankan asap dapur agar tetap ngepul (Taufik, 2002:1).

Menurut Bayan College (2010:1), dalam kajiannya tentang Curriculum Development Policy, menegaskan bahwa diyakini bahwa kurikulum adalah jantung dari setiap sistem pendidikan, dalam penyusunan kurikulum yang efektif akan memberikan kontribusi yang signifikan mencapai tujuan pendidikan. Dalam hal ini, kurikulum memuat semua materi dan kegiatan pembelajaran yang berlangsung di perguruan tinggi, atau sekolah dan dalam sistem yang dibutuhkan untuk membantu dan menilai bahwa hasil belajar. Ini berarti kurikulum mencakup kurikulum tertulis (panduan kurikulum), isi kurikulum (seperti yang diterapkan oleh dosen/ guru), ada evaluasi belajar (ditunjukkan oleh penilaian belajar mahasiswa/ siswa), pengembangan (untuk memastikan implementasi yang konsisten, pemantauan, dan pengawasan).

Menurut Jones \& Jones (2011:11), memberikanbahwadalamkurikulummengacu pada visi yang jelas dan berkomunikasi dengan cara yang inspiratif. menjelaskan perubahan positif bagi pendidikan, dan yang paling penting bagi para mahasiswa, memiliki alasan yang jelas untuk perubahan yang didasarkan pada fakta-fakta dan penelitian, mengakui dan menghargai kontribusi yang diberikan oleh individu, memiliki rencana komunikasi yang jelas sejak awal dan akhir, mencari kesempatan untuk pencapaian visi dan misi organisasi.

Seharusnya sebuah kurikulum dipatenkan selama beberapa lama agar dapat dilihat hasil dari pembelajaran tersebut. Jika kita melihat kenegara lain yang lebih maju, mereka memiliki SDM yang bagus, itu karena peserta didik mereka tidak dibuat bingung oleh perubahan yang begitu cepat. Kurikulum yang lama belum terserap langsung sudah terganti. Hal lain adalah banyaknya pemborosan biaya pendidikan termasuk untuk mencetak bukubuku yang pada akhirnya tidak terpakai,padahal seharusnya dapat digunakan untuk membiayai bidang-bidang lain dalam sektor pendidikan misalnya kesejahteraan guru, sehingga tidak akan terdengar lagi nada miris tentang nasib guru yang nyambi kerja jadi tukang ojek untuk mempertahankan asap dapur agar tetap ngepul (Taufik, 2002). 
Menurut Webster dalam Yamin (2012:21), kurikulum adalah jarak yang ditempuh oleh pelari dalam perlombaan. Kurikulum juga bermakna seperti kereta pacu di zaman lampau yitu suatu alat yang membawa seseorang dari garis start sampai finish. Dalam sektor pendidikan kurikulum berarti sejumlah mata pelajaran.

Kurikulum sebagai rencana pengajaran, rencana belajar murid, dan pengalaman belajar yang diperoleh murid dari sekolah/ madrasah. Kurikulum memuat sejumlah mata pelajaran yang membentuk intelektual manusia menguasai mata pelajaran, mencapai tujuan belajar (Hidayat, 2013: 19). Kurikulum dalam arti sempit adalah semua pelajaran baik teori maupun praktik yang diberikan kepada peserta didik selama mengikuti proses pendidikan tertentu, yang terbatas pada pemberian bekal pengetahuan dan keterampilan untuk kepentingan peserta didik dalam melanjutkan maupun memasuki dunia kerja. Sedangkan dalam pengertian luas, kurikulum adalah semua pengalaman yang diberikan oleh lembaga pendidikan kepada anak didik selama mngikuti pendidikan (Arikunto dan Lia, 2012: 95).

Tucker A, Deek F, Jones J, McCowan D, Stephenson C \& Verno A (2003) dalam kajiannya tentang "Computer Science: Final Report of the ACM K-12 Task Force CurriculumCommittee",mengusulkan sebuah model kurikulum yang dapat digunakan untuk mengintegrasikan komputer yang dapat membantu kelancaran penyampaian ilmu pengetahuan dan seluruh kompetensi pada sekolah dasar dan menengah, baik di Amerika Serikat dan di seluruh dunia. Hal ini menanggapi kebutuhan mendesak untuk memberikan koherensi akademik dalam mengikuti pertumbuhan dunia yang cepat dari komputerisasi dan teknologi di dunia modern, di samping kebutuhan untuk masyarakat terdidik yang dapat memanfaatkan teknologi yang paling efektif untuk kepentingan umat manusia.

Schwartz (2008) dalam kajiannya tentang "A Bit About Curriculum", mengemukakan bahwa kurikulum tidak hanya mencakup keseluruhan kegiatan, metode, materi, fisik, dan lingkungan sosial melalui pembelajaran secara keseluruhan, tetapi juga proses dinamis yang membentuk dan mengubah komponen ini. Beberapa lembaga, penyandang dana program, peserta didik itu sendiri, masyarakat lingkup nasional atau internasional, membentuk proses ini. Sementara istilah 'kurikulum' dapat merujuk keseluruhan pembelajaran yang terjadi di dalam dunia pendidikan.

Howard (2007), dalam kajiannya tentang "Curriculum Development", mengisyaratkan teorinya tentang pengembangan kurikulum adalah sederhana, logis, dan rasional, juga harus memperhatikan guru sebagai pendidik mulai dari pengalaman pembelajaran lebih holistik dan menilai hasil yang tidak begitu mudah diukur pada peserta didik. Menanggapi pendekatan kurikulum yang dianjurkan oleh Tyler, sering disebut pendekatan produk, kehadirannya apa yang dikenal sebagai pendekatan proses. Pendekatan ini paling terkait dengan pembelajaran.

Bunker \& Rod (2006) dalam kajiannya tentang "The Curriculum Model", mengemukakan bahwa muatan kurikulum merupakan dasar pemahaman kita tentang 'mengajar untuk memahami apa'. Tidak hanya menyediakan dasar teoritis dari mana untuk bekerja, juga memberikan bimbingan bagi mereka tentang perencanaan sebagai unsur awal dalam urutan waktu. Ketika kita diminta untuk menyajikan pembelajaran, untuk memimpin seminar dan melakukan kegiatan praktis, model merupakan titik awal untuk persiapan. Hadirnya pengamatan sebelum mengajar menunjukkan yang terbaik, serangkaian pelajaran yang sangat terstruktur bersandar berat pada pengajaran teknik, atau pelajaran terburuk yang bergantung pada anak-anak sendiri untuk mempertahankan minat dalam pembelajaran. Hal ini didasarkan pada pendapat bahwa pendekatan ini telah menemukan dan menganalisis: a) sebagian besar anak-anak mencapai sedikit keberhasilan karena penekanan pada kinerja, 
yaitu "melakukan sesuatu yang tidak efektif"; b) mayoritas sekolah unggulan "mengetahui" sangat sedikit tentang permainan; c) hasil seharusnya "terampil" menjadi pemain yang sebenarnya memiliki sifat fleksibel dalam bidang teknik dan minimnya kapasitas pengambilan keputusan; d) ketergantungan pengembangan guru / pelatih pemain; e) kegagalan untuk mengembangkan "berpikir" penonton dan "mengetahui" administrator pada suatu waktu ketika permainan (olahraga) merupakan bentuk penting dari hiburan dalam industri hiburan.

O’Neill G. (2010) dalam kajiannya tentang "Overview of Curriculum Models", mengemukakan ada koleksi model kurikulum yang diorganisirsekitarbagaimanamemproses kognitif peserta didik menerima informasi yang baik secara individu atau peningkatan pada kelompok. Ini dapat bervariasi dari model pengolahan kognitif informasi lebih lanjut dan lebih ke model sosial, yaitu konstruktivisme sosial. Pendekatan populer yang muncul di daerah ini (yang juga selaras dengan desain subject centered) adalah pengorganisasian kurikulum yang menantang, signifikan, konseptual, dan disiplin.

Undang-Undang Nomor 20 Tahun 2003 tentang Sistem Pendidikan Nasional menyebutkan bahwa kurikulum adalah seperangkat rencana dan pengaturan mengenai tujuan, isi, dan bahan pelajaran serta cara yang digunakan sebagai pedoman penyelenggaraan kegiatan pembelajaran untuk mencapai tujuan pendidikan tertentu. Berdasarkan pengertian tersebut, ada dua dimensi kurikulum, yang pertama adalah rencana dan pengaturan mengenai tujuan, isi, dan bahan pelajaran, sedangkan yang kedua adalah cara yang digunakan untuk kegiatan pembelajaran

\section{Penutup}

Pengelolaan kurikulum penyelenggaraan pendidikan guru sekolah dasar (PGSD), terkait dengan perencanaan, pelaksanaan, dan evaluasi. Perencanaan kurikulum penyelenggaraan pendidikan guru sekolah dasar (PGSD) masing-masing perguruan tinggi memiliki ciri khasnya sesuai dengan visi dan misinya. Pelaksanaan kurikulum dengan memperhatikan beban SKS yang bervariasi pada masing-masing perguruan tnggi. Evaluasi kurikulum didasarkan pada potensi dan dinamika masing-masing perguruang tinggi.

\section{Daftar Pustaka}

Alfidiyah, S. 2008. Hubungan Kondisi dan Penggunaan Sarana Prasarana Pendidikan dengan Keefektifan Pembelajaran Di Madrasah Aliyah Negeri (MAN) Se-Kabupaten Tulungagung. Skripsi. Jurusan Administrasi Pendidikan. Fakultas Ilmu Pendidikan. Universitas Negeri Malang.

Armstong, M. 2006. A Handbook of Human Resource Management Practice. London and Philadelphia: Kogan Page.

Anderson, L.W., Krathwohl, D.R., Airasian, P.W., Cruikshank, K.A., Mayer, R.E., Pintrich, P.R., Raths, J., Wittrock, M.C. 2000. A Taxonomy for Learning, Teaching, and Assessing: A revision of Bloom's Taxonomy of Educational Objectives. New York: Pearson, Allyn \& Bacon.

Arikunto, S. dan Lia Y. 2012. Manajemen Pendidikan. Yogyakarta: Aditiya Media.

Arkansas Departemen of Higer Education. 2013. "Education Costs". http://www. adhe.edu.

Bafadal, I. 2004. Manajemen Perlengkapan Sekolah. Jakarta : PT Bumikarsa.

Bayan College. 2010. "Curriculum Development Policy". http://www.bayan college. edu.om

Beare, H., 1989. Creating Excellent School. New York: Routlege. 
Bogdan. R. dan Taylor, S.J. 1993. Kualiiatif, Dasar-Dasar Penelilian, Terjemahan oleh A. Khozin Afandi. Surabaya: Usaha Nasional.

Braton, J. 2003. "Strategic Human Resource Management". http://www.palgrave. com

Bunker D \& Rod T. 2006. "The Curriculum Model". Journal University of Technology", Loughborough.http://education2.uvic.ca/faculty/thopper/tactic/model/curriculummodel. $p d f$

Burhanuddin. dkk, 2003. Manajemen Pendidikan. Malang: Universitas Negeri Malang.

Caliskan E.N. 2010. "The Impact of Strategic Human Resource Management on Organizational Performance". Journal of Naval Science and Engineering. Vol. 6, No.2. http://www.dho. edu.tr

Candra, A. 2012. "Manajemen Sarana \& Prasarana Pendidikan dan Keuangan Pendidikan”. Http://pendidikanadministrasi.blogspot.com

Crown. 2012. "The School Curriculum”. http://www.education.gov.uk/

David, F.R. 2004. Strategic Management Concepts. Terjemahan oleh Kresno Saroso. Jakarta: Indeks.

Davis Educational Foundation. 2012. "An Inquiry into the Rising Costs of Higher Education". http://www.davisfoundations.org.

Dean, J. 1998. Managing The Primary School. London: Routledge.

Denim, S. 2003. Agenda Pembaharuan Sistem Pendidikan. Yogyakarta: Pustaka Pelajar.

Denim, S. 2006. Visi Baru Manajemen Kampus. Jakarta: Bumi Aksara.

Depdiknas. 2006. Panduan Penyusunan Rencana Pengembangan Sekolah. Jakarta: Dirjen Dikdasmen.

Fattah, N. 1996. Landasan Manajemen Pendidikan. Bandung: Remaja Rosdakarya. . 2009. Ekonomi dan Pembiayaan Pendidikan. Bandung: Remaja Rosdakarya. 2012. Standar Pembiayaan Pendidikan. Bandung: Remaja Rosdakarya.

Gaspersz, V. 2006. Total Quality Manajemen untuk Praktisi Bisnis dan Industri. Jakarta: Gramedia Pustaka Utama.

Glasser \& Strauss. 1974. Strategic Human Resource Management, United States Of America, Dave Shaut

Gorton, R. A. 1991. School-Based Leadership: Challenges and Oportunties. San Diego: Wm. C. Brown Publisher.

Guba, e. G., \& Lincoln, Y. S. 1981. Effective Evaluation: Inproving the Esefulness of Evaluation Results Through Responsive and Naturalistic Approaches, San Fransisco: Jossey-Bas Publishers.

Hakim, C. 1997. Research Design. London: Routledge.

Hanson, E. M. 1991. Educational and Organizational Behavior. Boston: Allyn and Bacon.

Harsono, 2008. Model-model Pengelolaan Perguruan Tinggi. Yogyakarta: Pustaka Pelajar. . 2008. Konsep Dasar Mikro, Meso, dan Makro Pembiayaan Pendidikan. Yogyakarta: Surajaya Press.

Hidayat, S. 2013. Pengembangan Kurikulum Baru. Bandung: Remaja Rosda Karya. 
Howard, J. 2007. "Curriculum Development". Journal Department of Education Elon University Summer 2007. http://www.pdx.edu/sites/www.pdx.edu. cae/ files/media assets/Howard.pdf

Hoy, C., Bayne-Jardine, C., and Wood, M. 2000. Improving Quality in Education. London: Falmer Press.

Huemann, M. 2011. "Considering Human Resource Management when Developing A ProjectOriented Company: Case Study Of A Telecommunication Company". http://cfile10. uf.tistory.com/attach/174303464D32EA43313CEB

Isjoni. 2006. Pendidikan sebagai Investasi Masa Depan. Jakarta: Yayasan Obor Indonesia.

James, C., and Peter, P. 1998. "The Practice of Educational Marketing in Schools," dalam Educational Management: Strategy, Quality, and Resources. Ed. Philadelphia: Open University Press.

Jones, CAJ \& Anderson, M. 2001. "Managing Curriculum Change". Learning and Skills Development Agency, 3 Citadel Place, Tinwor th Street, London SE11 5EF Tel 0207962 1066 Fax 02078405401 http://www.LSagency. org.uk or http://dera.ioe.ac.uk

Karpathy A \& Panne M. 2010. "Curriculum Learning for Motor Skills”. Journal University of British Columbia http://cs.stanford.edu/people/karpathy/ papers/ motor-curriculumfull.pdf

Knzevich, D. L 1984. Administration of Public Education. New York: Harper and Row.

Kouwenhoven W. 2010. “Competence-Based Curriculum Development In Higher Education: Some African Experiences”. http://dare.ubvu.vu.nldevelopment. pdf

Kotler, P. 1997. Manajemen Pemasaran; Analisis, Perencanaan, Implementasi dan Control. Jilid I. Terjemahan oleh Hendra Teguh dan Rony A. Ruli. Jakarta: PT. Prenhalindo.

Kotler, P. 2002. Marketing Management, Millennium Edition. New Jersey, Usa: Prentice-Hall.

Kotler, P., dan Amstrong, G. 1993. Marketing An Introduction. New Jersey, Usa: PrenticeHall.

Lackney Jeffery A. \& Picus. Lawrence O. 2010. Schools, Facility, Construction, and Educational. http://education.stateuniversity.com

Lincoln. Y.S.. \& Guba. E.G.L. 1985. Naturalise Inquiry. Beverly Hill, CA: SAGE Publications, Inc.,

Linda R.B. 2008. “Certified Elementary School Teacher”. Journal of Main St. Sometown, IN 47000 (555)555-5555 http://linda@somedomain.com

McKimm J. 2003. "Curriculum Design \& Development”. Journal Head of Curriculum Development, School of Medicine Imperial College Centre for Educational. http://www. faculty.londondeanery.ac.uk/e-learning/

Marshal, C., \& Rossman, G. B. 1989. Designing Qualitative Research. Newbury Park, California: Sage Publication.

Moedjiarto. 2002. Kampus Unggul: Metodologi untuk Meningkatkan Mutu Pendidikan. Surabaya: Duta Graham Pustaka.

Moharman, S. A., Et. Al. 1994. School Based Management: Organizing for High Performance. San Francisco.

Miles, m. B., dan Huberman, A. M. 1984. Qualitative Data Analysis. London: Sage Publications. 
Miles. M.B. \& Huberman A.M. 1992. Analisis Dcua Kuuliiaiif. Buku Sumber tentang Metodemetode Baru. Terjemahan oleh Tjetjep Rohendi Rohidi. Jakarta; penerbit Universitas Indonesia (UI-PRESS).

Moleong. L.J. 2005. Melodologi Penefitian Kualiialif Edisi Revisi. Bandung: PT

Mulyono. 2008. Manajemen Administrasi dan Organisasi Pendidikan. Yogyakarta: Ar-Russ Media.

Naresh K, Vipan K and Neelam K. 2010. "Educational Infrastructure in India". http://www. nistads.res.in/indiasnt2008/t1humanresources/t1 hr3.htm

Nasution. S. 2002. Metode Penilaian Naturalistik Kualitafif. Bandung: Penerbit y Tarsito.

Oedb. 2012. "Teachers in Kindergarten, Elementary, Middle, and Secondary Schools". http:// oedb.org/fast-track-careers-math/teacher-math.

Owen, R. G. 1995. Organizational Behavior In Education. Boston: Allyn and Bacon.

Patton, M.Q. 1980. Qualitative Evaluation Methods. London: Sage Publication.

Peraturan Pemerintah Republik Indonesia Nomor 66 Tahun 2010 Tentang Perubahan Atas Peraturan Pemerintah Nomor 17 Tahun 2010 Tentang Pengelolaan dan Penyelenggaraan Pendidikan.

Plessis, DLE. 2005. "Managing Curriculum”.http://uir.unisa.ac.za

Pintrich, P.R., Raths, J., Wittrock, M.C. (2000). A Taxonomy for Learning, Teaching, and Assessing: A revision of Bloom's Taxonomy of Educational Objectives. New York: Pearson, Allyn \& Bacon.

Prideaux. D. 2003. "Curriculum Design :ABC of Learning and Teaching In Medicine". BMJ volume 3261 february 2003 bmj.com http://www. son.washington.edu/ faculty/support/ preceptors/curriculum.pdf

Purwanto, Ng.M. 2009.Administrasi dan Supervisi Pendidikan. Bandung: Remaja Rosdakarya

Raiser, David. 2011. “Elementary School Teacher Salary \& Career Outlook”. http://www. schools.com/news/elementary-school-teacher-salary-career-outlook.html

Robbins, S,P. 1979. Organizational Behavior. Siding: Pretice Hall.

Rohiat, 2010. Manajemen Sekolah : Teori Dasar dan Praktik. Bandung : Refika Aditama.

Rosid, N.S. 2012. “Konsep Sarana dan Prasarana Pendidikan”. http://www, wordpress.com.

Sallis, E. 2011. Total Quality Management In Education. Terjemahan oleh Ahmad Ali Riadi dan Fahrurrozi. Yogyakarta: IRCiSoD.

Salim, A. 2001. Teori dan Paradigm Penelitian Sosial. Yogyakarta: Tiara Wacana.

Sejathi. 2011. "Pengertian Sumber Daya Manusia". http://www.wordpress.com.

Siddiqui, Mohd. Akhtar. 2009. "National Curriculum Framework for Teacher Education". http://www.ncte-india.org.

Sudibyo, Bambang. 2007. Standar Sarana dan Prasarana Sekolah/Madrasah Pendidikan Umum. Jakarta : Depdiknas.

Sudrajat, Akhmad. 2011. Kurikulum dan Pembelajaran dalam Paradigma Baru. Yogyakarta: Paramitra Publishing.

Suherman, E. 2012.Kiat Sukses Membangun Sumber Daya Manusia Indonesia Melalui Pendidikan dan Pelatihan Kewirausahaan. Bandung: Alfabeta. 
Sulianto, Joko, Aries Tika Damayani, Ervina Eka Subekti, Ryky Mandar Sary. 2011. Studi Pelacakan (Tracer Study) Kepuasan Mahasiswa Terhadap Pelayanan Akademik Pembelajaran dan Sarana Prasarana Progdi PGSD IKIP PGRI Semarang. Semarang: IKIP PGRI Semarang.

Supriadi, D. 2010. Satuan Biaya Pendidikan. Bandung: Remja Rosda Karya.

Sutama, 2010. Metode Penelitian Pendidikan: Kuantitatif, Kualitatif, PTK, $R \&$ D. Surakarta: Fairuz Media.

Taufik, 2002. "Perubahan Kurikulum Dapat Menentukan Nasib Baik Hasil Pendidikan". http://www.diknas.go.id

Tazaki T, Nakajima T, \& Nishikawa K. 2001. "Management of Infrastructure Facilities as Disaster Protection". http://www.pwri.go.jp/eng/ujnr/joint/34/ paper/81nisika.pdf

Tilaar, H.A.R. 2005. Manifesto Pendidikan Nasional (Tinjauan dari PerpsektifPostmodernisme dan Studi Kultural. Jakarta : Kompas.

Transylvania University, 2012. Human Resources Employee Benefits Summary. http://www. transy.edu/about/hr/benefitsummary.htm?mi=employment.

Undang-undang Republik Indonesia Nomor 20 Tahun 2003 tentang Sistem Pendidikan Nasional.

Uwes, S. 1999. Manajemen Pengembangan Mutu Dosen. Jakarta: Logos Wacana lmu.

Wiyono, B.D 2002. Melodologi Pernelitian Kualilalif. Malang: Jurusan Administrasi Pendidikan. Fakultas llmu Pendidikan. Universitas Negeri Malang.

Wiley, M.G.. 2012. "Curriculum”. http://en.wikipedia.org/wiki/ Curriculum

Wolf P., Hill A \& Evers F . 2006. "Handbook for Curriculum Assessment Winter 2006”. Journal University of Guelph, Guelph, Ontario, Canada N1G 2W1 http://www.uoguelph.ca/tss/ resources/pdfs/HbonCurriculumAssmt.pdf

Yamin, M. 2012. Panduan Manajemen Mutu: Kurikulum Pendidikan. DIVA Press.

Yin, R. 1984. Case Study Research: Design and Methods. London: Sage Publication.

Yixin, 2012. "Analysis on the Defrayal in Electronic Commerce of China Department of Industry and Commerce Management", Journal Hunan University of Finance and Economics. P.R.China, 410205.http://luoguiyuan@sina.com.

Zaini, M. 2006. Pengemban Kurikulum. Surabaya : eLKAP. Syracuse University Press.

Zaini, M. 2006. Pengembangan Kurikulum : KonsepImplementasi Evaluasi dan Inovasi. Surabaya: Elkaf.

Zazin, N. 2011, Gerakan Menata Mutu Pendidikan : Teori dan Aplikasi. Yogjakarta: Ar Ruzz Media. 